\title{
地震時における大規模宅地盛土斜面の不安定化予測 Earthquake risk assessments of large residential fill-slope in urban areas
}

\author{
釜井俊孝 ${ }^{\mathrm{a})}$ ，守隨治雄 ${ }^{\mathrm{b})}$ ，笠原亮一c)，小林慶之 ${ }^{\mathrm{d})}$ \\ Toshitaka KAMAI, Haruo SHUZUI, Ryouichi KASAHARA and Yoshiyuki KOBAYASHI
}

\begin{abstract}
Recent destructive earthquakes in urban regions, such as the1978Miyagiken-oki earthquake, the1993Kushiro-oki earthquake and the1995Hyougoken-nanbu earthquake, have triggered landslides in many gentle slopes of residential areas around Sendai, Kushiro, Nishinomiya and Kobe. The earthquake-induced slope instability that has occurred is closely related to these artificial landforms, especially valley fills (embankments). More than $60 \%$ of the unstable slopes in the Kobe-Nishinomiya urban region are in artificial valley fills. This instability was caused by strong ground movements during the1995Hyougoken-nanbu earthquake.

Investigation of past artificial landform changes and multi-variate analysis of case studies of past earthquake disasters show that differences in the shape of fills, such as depth, width, inclination angle of the base, and cross-sectional form, may be the key discriminating factors of slope instability. Triggering mechanisms (e.g. earthquakes) need to be considered in the analysis for accurate estimation, however, it is difficult to include earthquake parameters in such linear multi-variate analysis (quantification theory II). Neural network analysis is applied to assess large fill slope instability in urban residential areas. The developed neural network model including both causative factors (shape of fills, groundwater condition, age of construction) and the triggering factors (distance from the fault, moment magnitude, direction to fault) was independently checked against another data set and sensitivity analysis was conducted. The neural network model appears to have advantages over the multi-variate analysis. It should be possible to conduct landslide hazard mapping in urban residential areas by using the newly proposed neural network model.
\end{abstract}

Key words : valley fills, landslide, urban region, neural network, hazard map

\section{和文要旨}

高度経済成長期おいて，政策的に誘導された大都市への人口集中は，郊外に向かう宅地開発圧力となり，新たな斜面災害のリス クを增大させた。1978年宮城県沖地震，1993年釧路沖地震，1995年兵庫県南部地震等，都市に被害を与えた地震では，都市域に形 成されていた多数の大規模な宅地盛土（多くは谷埋め盛土）が変動（地すべり）した。これらの災害事例に関しては，盛土の形状 (厚さ，幅，底面の傾斜及びそれらの比）と地下水の状況が素因として重要であることが判明しているが, 誘因である地震の特性を 考慮した子測モデルについての検討は不十分であった。そこで, 上記の 3 地震における事例 314 例について, 素因（盛土の厚さ，幅， 厚さ／幅比, 底面の傾斜, 地下水の量, 造成年代) と誘因（震源断層からの距離と方向，モーメントマグニチュード）を入力とし, 変動の有無を出力とするニューラルネットワークモデル (Back propagation法) を作成した。さらに，このモデルを用いた不安定化 予測を試みた結果, 学習群 (阪神, 仙台, 釧路：214例）で約95\%, 予測 (認識) 群 (阪神, 仙台：100例) で約 $92 \%$ の正解率を有 する良好な判別モデルを構築することができた。このモデルを東京一横浜地域の360例に適用した結果は, 釜井ほか (2002) の多変 量解析（数量化II 類）とほほ同様の傾向を示した。現実にはあらゆる斜面について詳細な調査と解析を行うことは洤難であるため, 今回提案した簡易かつ合理的な不安定化予測手法は, ハザードマップの作成や対策の害施において有用である。

キーワード：谷埋め盛土, 地すべり, 都市域, ニューラルネットワーク, ハザードマップ

\section{1. はじめに}

高度経済成長期において，政策的に誘導された大都市 への人口集中は, 郊外に向かう宅地開発圧力となり，新 たな斜面災害のリスクを増大させた。1978年宮城県沖地 震, 1993年釧路沖地震, 1995年兵庫県南部地震等, 都市に 被害を与えた地震では, 都市域に形成されていた多数の 大規模な宅地盛土（多くは谷埋め盛土）が変動した。こ れらの現象は, 土塊の流動性が高い場合は「土砂流動」 や「側方流動」と呼ばれている。しかし, 変動した事例 の多くは, 顕著な水平変位を伴う流動性の低い移動体の 変動であり, 運動の形態としてはむしろ地すべりに類似 していた。したがって，こうした盛土の変動を，ここで

\footnotetext{
* 連絡著者/corresponding author

a) 京都大学防災研究所

DPRI, Kyoto University

T611-0011 宇治市五ヶ生

Gokasho Uji city, Kyoto, Japan

b) 日本工営(株)

Nippon Koei Co. Ltd.

c) 日本工営侏）(元京都大学大学院）

Nippon Koei Co. Ltd. (formerly with Graduate School of Kyoto University)
d) 日本工営俰) (元日本大学大学院)

Nippon Koei Co. Ltd. (formerly with Graduate School of Nihon University)
}

\section{は「地すべり」と呼ぶことにする。}

既往の変動事例に関して地形・地質，及び土質工学的 検討が進められた結果，谷埋め盛土の地すべりは自然斜 面の崩壊と異なり, 発生する場と誘因（地震）があらか じめほぼ限定され，土質がほぼ均一であるという特徵が 明らかになっている。そこで主として変動事例と非変動 事例との対比をもとに, 盛土底面の形状（造成以前の地 形）や地下水，造成年代等の素因を要因とした多変量解 析（数量化II 類）が試みられ，簡便な変動予测法が提案 されている（Kamai et. al., 2000, 釜井ほか, 2002）。

しかし，こうした多変量解析を用いた予測法において は誘因（地震）を評価することが難しく，震動に関する 要因の取り扱いは曖昧なままであった。さらに地震毎に 得られる事例数に偏りがある場合にはその影響を強く受 けるため, 事例数が少ない地震のタイプに対しては予測 精度が著しく低下し, 事実上適用可能な地震が限定され ていた。また, 数量化法の場合, 要因のカテゴリー区分 （グループ分類）を行う必要があり，このことが解析を 
染意的なものにする危険性を有している。すなわち，カ テゴリー区分は事実上，試行錯誤的に行うことが一般的 であるうえ，それを $\mathrm{AIC}$ 等の情報量基準によって評価し たとしても，誘因の条件を取り入れていない場合，他の 地震にそのカテゴリー区分をそのまま適用することは難 しい。

そこで本研究では，簡便性を保持しながら同時に上記 の問題点を解決し高精度の予測手法を提案するため, 非 線形予測手法であるニューラルネットワーク（Back propagation法）を用いた谷埋め盛土の変動・非変動に 関する不安定化予測を行った。ニューラルネットワーク では, 地震に関する要因をシステムに含めることが可能 であり，カテゴリー区分が原則として不要であるため, 上記の問題点の多くは解決され，より高精度の変動予測 モデルの構築を試みることが可能である。

\section{2. 谷埋め盛土の地すべり}

地震時に住宅地の盛土地盤が変形・変動する事例は, 十勝沖地震, 宮城県沖地震, 千葉県東方沖地震, 釧路沖 地震, 北海道東方沖地震, 兵庫県南部地震等過去の地震 においてしばしば発生している（井口，1995）。このう ち，1978年の宮城県沖地震，1993年の釧路沖地震，1995 年の兵庫県南部地震においては，都市域に分布する谷埋 め盛土について多数の変動事例が得られている（浅田， 1982, 千葉，1996，柳 澤ほか, 1993, Kamai et. al., 2000, 釜井ほか, 2002)。その多くはクラックや沈下等 の地表変状の性質から，移動体（変動ユニット）中に頭 部，側部，末端部を識別することが可能であり，全体が 地すべりとして変動したと考えられる。実際にその一部 は, 宮城県沖地震の際の寿山団地や兵庫県南部地震によ る仁川の崩壊の様に土塊の内部が液状化し，崩壊土砂が 長距離を流動したが，その他の大部分の事例では拘束条 件や人工構造物, 地下水位等の制約により, 全般的な流 動には発展しなかった。しかし，こうした非流動的な変 動においても多くの住宅が損傷しており，この夕イプの 災害が地域社会に与えた影響は大きく, 谷埋め盛土の地 すべりは防災上重要な斜面災害のタイプであると考えら れる。

本研究において谷埋め盛土の地すべり変動の有無は, 原則として現地踏査による判定に従っている。すなわち, 踏査の段階で視認される程度の地表変状の組み合わせを 基に, 変形が比較的顕著であり，同時に地すべり移動体 （変動ユニット）が認定される場合を変動事例（地すべ り), それ以外を非変動事例と判定した。一部の事例の 様に過去の文献をもとに検討を行う場合は, 踏査結果の わかる図面や写真をもとに判断した。したがって，切り 盛り境界等の地表部にクラックが形成された場合でも, 斜面方向に地すべり移動体（変動ユニット）が認定でき ず単なる盛土の沈下と判断される場合は, 変動事例（地 すべり）から除外した。
今回の地表踏査では, 地域全体が網羅的に調査されて いる。したがって, 地表踏査結果は, 広域に分布する谷 埋め盛土地すべりの現時点における最も信頼しうる情報 源であると考えられる。しかし, 地表踏查によって変動 の有無を判定する場合, 基準を数值等で明確にすること は困難である。そのため, 広域に多数分布する盛土を同 じ精度で分類するためには，変動のランク区分はできる だけ単純なことが望ましい。そこで今回は，最も単純に， 変動, 非変動の二分割とした。踏査に熟練すれば，地域 内に分布する多数の谷埋め盛土の中から, 上記の “変動 事例”を抜き出すことは難しくない。したがって，それ らを除外した “非変動事例”も現実的には比較的容易に 発見することができる。こうした変動事例では，何らか の“被害”が顕著に発生していると考えられ，広域にお いてこれらを抽出することは，防災上の意義が大きいと 考えられる。

\section{3. ニューラルネットによる変動予測モデル}

\section{1 ニューラルネットワークの概要}

ニューラルネットワークは脳の中の神経細胞（ニュー ロン）とその繋がり＝ネットワークをモデル化した人工 知能 (AI) の一つである。ニューラルネットワークの 特徵の一つは学習と自己組織化能力を持っている点であ る。すなわち, ニューラルネットワークは外部環境に合 う様に自分自身を変化させて適応することが可能である。 ニューラルネットワークはニューロンの連結の仕方に よって階層型ネットワークと相互結合型ネットワークに 区分される。階層型ネットワークは層状に並べられた ニューロン間を前の層から次の層へ一方向にのみ信号が 伝わり，入力信号に対して出力信号が一意的に定まる。 本研究では相互結合型ネットワークを用いないので, 階 層型ネットワークをニューラルネットワークと呼ぶこと にする。任意のパターンの識別には，最低 3 層（入力層, 中間層, 出力層) あれば可能であることが知られている ため, 本研究においても 3 層のニューラルネットワーク を使用した。

ニューラルネットモデルの具体的解法として，ここで はバックプロパゲーション法 (Back Propagation : BP法) を採用した。BP法は矛盾を含むデータセットであって も誤差を最小とするネットワークモデルを構築すること が可能である。BP法のネットワークは, 入力層, 中間 層, 出力層それぞれの層間ではニューロンは密接に結合 しているが，同じ層内のニューロン間は結合していない (図 - 1)。図-2は, BP法の計算過程を示している(白 木ほか，1998）。入力層に展開された学習パターンは中 間層から出力層へ伝わり, 出力層で出力值 $O$ と教師值 $D$ (実際の結果) が比較される。そして出力值 $O$ と教師值 $D$ 間の誤差 $E$ が最小となるように結合重み $W, V$ やし い值 $S$ を調整することによって学習が行われる。䛊差 $E$ は, 出力值 $O$ の関数であり, また出力値 $O$ は中間層と出 


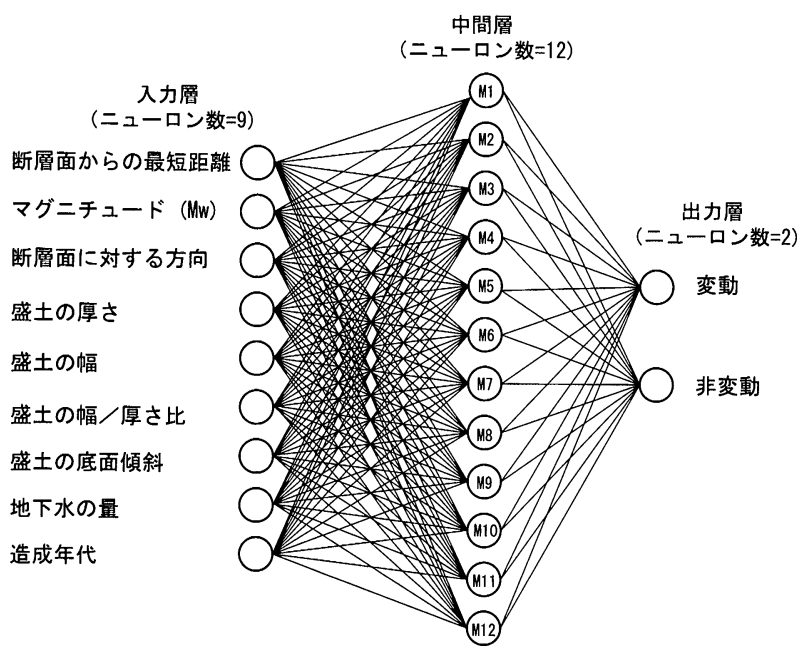

図ー 1 ニューラルネットワークによる予測モデルの構造 Fig. 1 Neural network structure of the prediction model

力層間の結合重み $V$ 関数であるから，誤差 $E$ を最小に

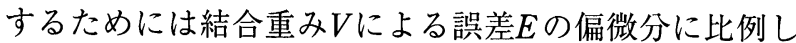
た量だけ，結合重みVを変化させれば良い。このときの 比例係数を学習率 $\alpha$ と呼ぶ。入力層と中間層間の結合重 みWの更新も同様に行う。このように誤差の減少のた めの信号が出力層から入力層へ伝えられることから, BP 法は誤差逆伝播法とも呼ばれている。

\section{2 解析に用いる要因とデータセット}

\section{1) 要因}

Kamai et. al. (2000) 及び釜井ほか（2002）は兵庫県 南部地震, 宮城県沖地震の事例をもとに, 谷埋め盛土の 変動に関する様々な素因について解析した。その結果， 変動・非変動事例の判別において盛土の形状, 地下水, 形成年代に関する 6 要因に素因としての有意性が認めら れた。そこで本研究では，これらに誘因としての震動特 性に関連する「断層面からの最短距離」,「モーメントマ グニチュード」，「断層面に対する方向」の 3 要因を加え， 以下の 9 個の要因でニューラルネットワークを構成する ことにした。

(1)断層面からの最短距離

谷埋め盛土の変動に影響を及ぼすと考えられる最大 速度の距離減衰についてはいくつかの実験式が提案さ れている（例えば，Midorikawa，1994）。そうした式 のパラメータは, 主に距離とマグニチュードである。 距離については震央距離, 震源距離, 断層からの距離, 断層面からの最短距離と様々である。震央距離や震源 距離はデータの作成が容易であるが，直下型地震のよ うに被害域が震源断層に近い場合，点震源からの距離 では被害の害態を正しく表現できない可能性がある。 さらに今回は，使用するデー夕に直下型地震の兵庫県 南部地震の事例が多い。これらのことから, 今回は距

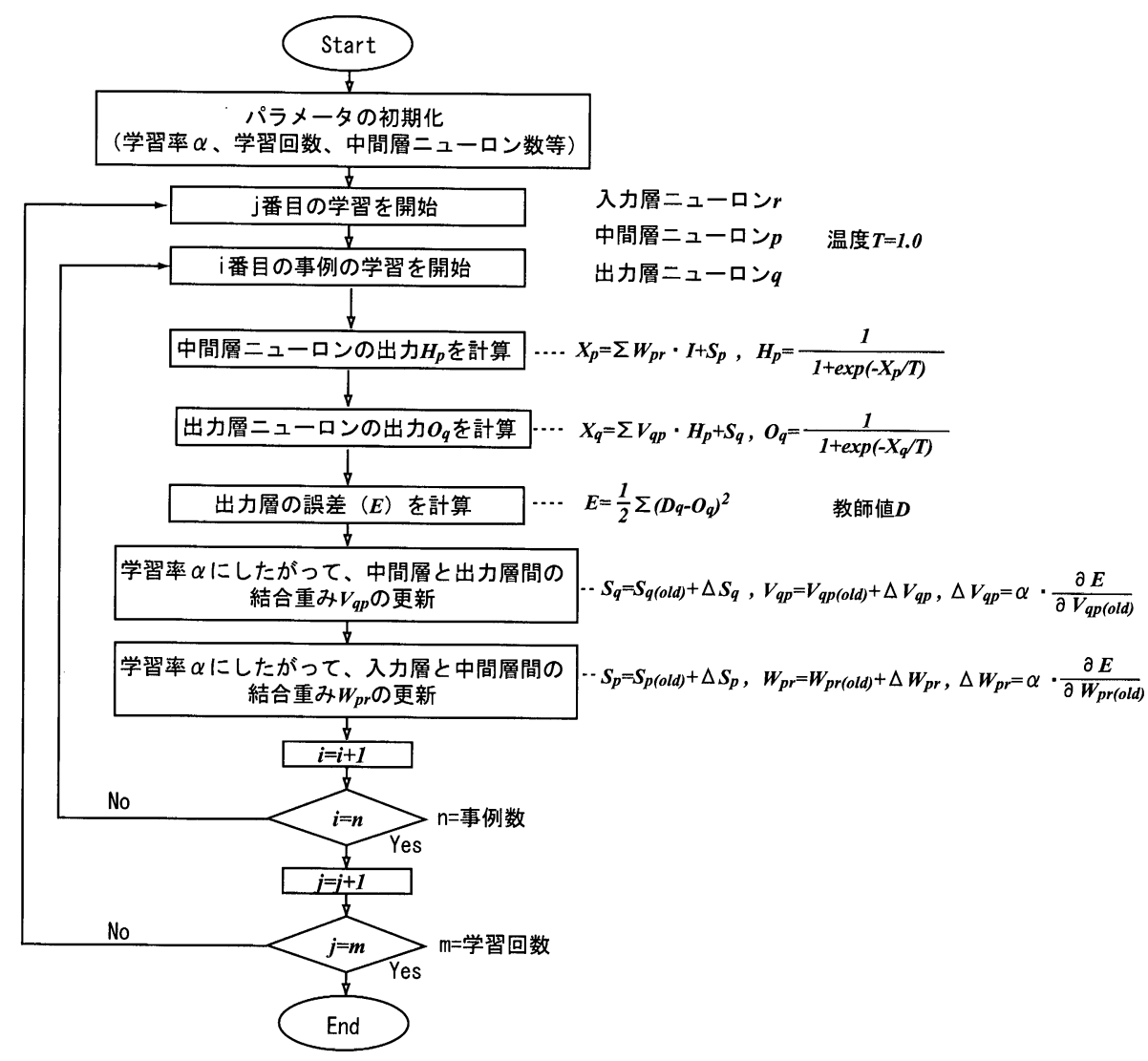

図一２ バックプロパゲーション法 (BP法) の解析フロー

Fig. 2 Flowchart of the back propagation method 
離減衰の影響を表現する要因として，断層面からの最 短距離を使用する。この結果，兵庫県南部地震におけ る事例の大半が, 断層面から $7 \mathrm{~km}$ 以内の震源域に含 まれることになる。

また，断層から離れるにつれて，最大速度が減衰す ると同時に，周波数特性（卓越周期等）も変化する。 したがって，この要因は，距離による卓越周期等の周 波数特性の変化についても陰に表現していると考えら れる。

(2)モーメントマグニチュード

距離に関する要因として断層面からの最短距離を採 用しているので, マグニチュードに関してもモーメン トマグニチュード（Mw）を使用する。

(3)断層面に対する方向

断層面から盛土の長軸がどの方向であったかを計算 し，要因として使用した。実際には断層の走向と長軸 方向の内積（cos（断層の走向と長軸方向がなす角）の 絶対値）を用いた。兵庫県南部地震では，震源域にお いて断層直交成分の地震動 (速度, 振幅) が卓越して いた（地盤工学会，1996）。長軸すなわち斜面方向が 断層に対してどの方向であったかは，盛土の摇れに影 響を与えたと考えられる。

(4)盛土の厚さ

盛土の形状を記述する基本的パラメー夕の一つであ り，盛土の質量に関連することから変動の有無に大き な影響を及ぼす要因と考えられる。図－3は，兵庫県 南部地震における谷埋め盛土の変動・非変動事例につ いて，盛土の形状に関するパラメータのヒストグラム
と変動率（変動事例数 $\div$ ヒストグラム横軸の各区分で の総数）を示している。谷埋め盛土の変動率は盛土が 厚くなるにつれて低下し, 盛土厚が薄いほど変動しや すい傾向が明瞭に認められた。

(5)盛土の幅

盛土の形状を記述する基本的なパラメータとして使 用する。一般に幅が広ければ側方拘束の影響が弱まる ため, 変動が発生しやすいと考えられる。兵庫県南部 地震ではこの傾向が明瞭に認められた（図-3）。

(6)盛土の幅／厚さ比

盛土の横断形状を記述する基本的無次元数である。 谷埋め盛土の厚さ（=谷の深さ）に対して幅の広い盛 土と幅の狭い盛土とでは, 被害の程度が異なるという 経験的事実から導入した。三次元的なすべりを考えた 場合の側面の抵抗を表現すると考えられるが，谷埋め 盛土の底面には軟弱な地盤が残されていることが多く, 盛土側面の抵抗は変動の有無に大きな影響を及ぼす要 因と考えられる。兵庫県南部地震ではこの傾向が明瞭 であり, 幅/厚さ比が20以下の領域では，谷埋め盛土 の変動率は幅／厚さ比が大きくなるにつれて増加した (図 - 3)。一方, 幅/厚さ比が25以上の領域では, 非 変動事例がほとんど見られなくなるため，変動率は 80\%以上でほぼ一定となる。区分毎のデー夕数は少な いが, 変動事例と非変動事例の幅／厚さ比の分布は異 なっており, 最頻值が変動事例では20前後であるのに 対し，非変動事例では 5 以下である。

幅／厚さ比は盛土底面の形状に強く関連し，幅／厚 さ比が小さいほど谷（盛土底面）の横断形状はV字型
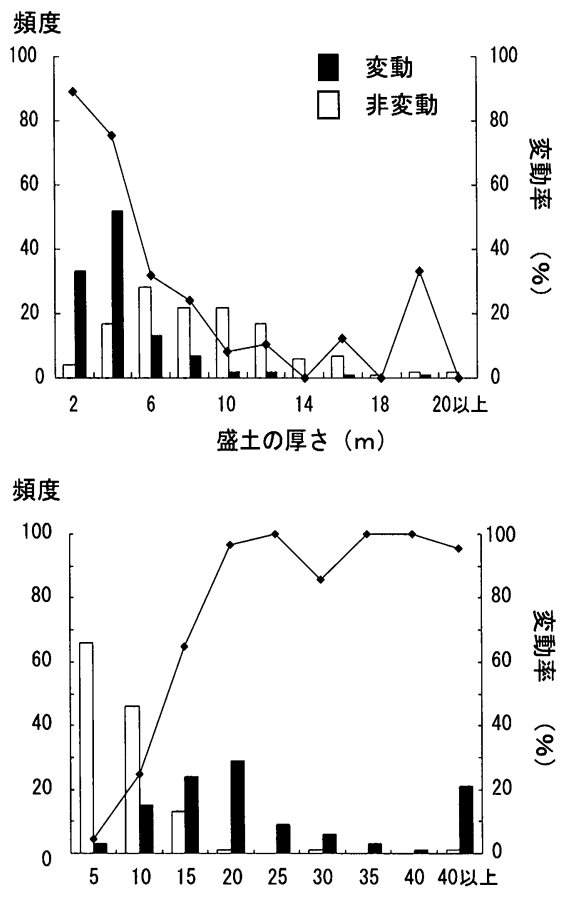

幅/厚さ
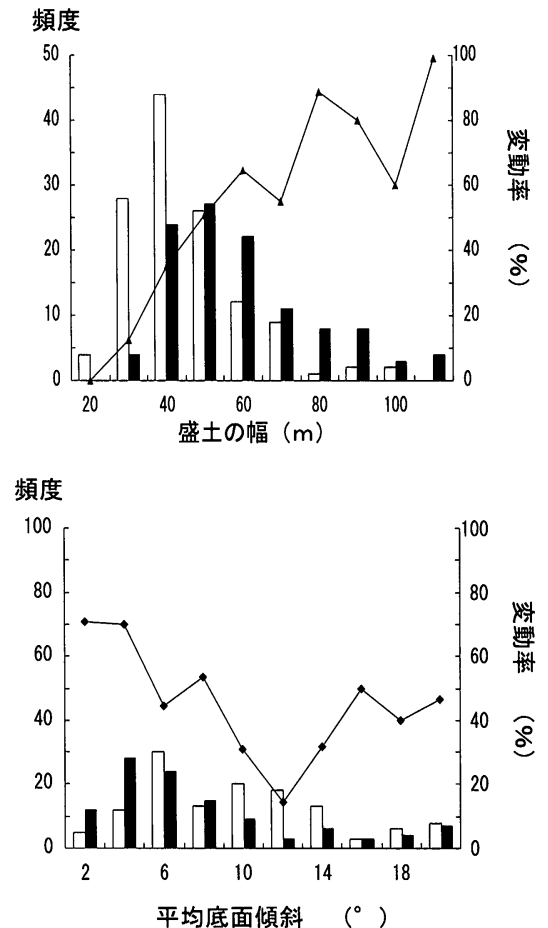

図一3 形状に関する各要因の頻度分布（兵庫県南部地震）

Fig. 3 Histograms of shape factors (Hyougoken-nanbu earthquake) 
に近く，幅/厚さ比が大きいほど谷の横断形状は㿼 形・お椀型に近くなる。このことと，谷埋め盛土の変 動率は盛土が厚くなるにつれて低下し，変動した盛土 の大部分が 6 m以下であったことから，変動事例の多 くは底の浅いお椀型〜血形の横断形状をした盛土で あったと考えられる。

(7)盛土の底面傾斜

盛土の形状を記述する基本的なパラメータとして使 用する。傾斜は底面の部位によって異なるため, 谷中 央の最深部を通る縦断勾配を底面傾斜として定義した。 一般に底面の傾斜が急であれば変動が発生しやすいと 考えられるが, 兵庫県南部地震の事例では, その傾向 が認められなかった（図－3）。逆に，データのバラ ツキによる10～14度付近の急激な低下を除けば，全体 に傾斜が増加するにつれて変動率は漸減している。こ れは, 形状に関する要因（厚さ, 幅, 底面傾斜) が互 いに独立でないため，他の支配的要因（変動の有無に 強く影響を及ぼす要因）によるバイアスが発生してい るためと考えられる。このことは，非線形予測手法の 必要性を示唆するものと考えられる。

(8)地下水の量

谷埋め盛土の内部にはしばしば地下水が貯留されて おり，変動の有無に影響を与える要因と考えられる。 しかし, 地下水位の情報を定量的に把握できる地点は 限られている。そこで, 開発以前の土地利用状況（水 田か畑か等）や溜め池の有無，湧水の有無に関する情 報をもとに, 地下水の量が豊富か少ないかを推定し解 析に使用した。解析においては, 地下水にそしい場合 を 0 ，豊富な場合を 1 として入力データとした。兵庫 県南部地震の事例では, 地下水位が低く盛土底面以下 (入力值 0 ) と判定された地点の変動率は, 約 $9 \%(4 /$ 46箇所）であったのに対し，地下水位が高く盛り土中 に形成されていると判定された場合（入力值 1 ）の変 動率は, 約54\%（113/210箇所）であり, 顕著な相違 が見られた。

(9)造成年代

宅地造成に関する法令・規則の多くが，1965年〜 1975年にかけて整備された。こうした，規制の状況は 谷埋め盛土の品質に影響を及ぼしたと考えられる。そ こで, 造成年代を1975年以前と以後に区分し解析に使 用した。解析においては, 1974年以前の造成の場合を $0 ， 1975$ 年以後の造成の場合を 1 として入力データと した。兵庫県南部地震の事例では，1974年以前に造成 された盛土（大力值 0 ) の変動率は, 約47\% (104/222 箇所）であったのに対し，1975年以降に造成された盛 土（入力值 1 ）の変動率は, 約35\% (12/34箇所) で あった。阪神間の都市域では，1970年代までに開発が 一段落しているため母集団の規模に違いがあるが, 1974年以前に造成された盛土の変動率は, それ以後に 造成された盛土よりもやや高いといえる。
上記の様に地形に関する要因においては変動・非変動 事例間に相違が認められ，しかもデータの収集が容易で ある。これに対し，盛土の換算N值（簡易貫入試験の結 果を標準貫入試験に換算した值）は連続した頻度分布を 示し，強度は全体に軟弱である（図-4上）。さらに， 変動しなかった盛土でも表層部を除いて強度が極めて低 い事例がしばしば認められた（図一 4 下)。すなわち, 少なくとも現時点の調查結果では, 谷埋め盛土のN值は, 非変動事例も含めて母集団全体で值が低いため, 変動と 非変動を識別する上で有効な指標とは言えない。さらに 広域に多数分布する全ての盛土において，N值の収集は 現実に困難である。したがって，本研究ではN值を要因 として使用しなかった。

2) データセット

上記の要因を全て含んだデータセットを以下の 2 種類 用意した。

(1)過去の地震による変動・非変動事例

兵庫県南部地震による神戸市長田区〜京都府向日市 の事例 $(256$, うち変動事例117), 宮城県沖地震によ る仙台都市域の事例 (53, うち変動事例10), 釧路沖 地震による釧路市の事例（4，うち変動事例 2 ）を収 集した。図 -5 に各地震の推定断層の位置, 震央, モーメントマグニチュードを示す。

谷埋め盛土の形状に関するデータセットの作成方法 は，釜井ほか (2002) と同様である。すなわち，各地 域における 1 万分の 1 旧版地形図 (開発以前の地形図) を収集し，数值化してDEM（数值地形モデル）を作
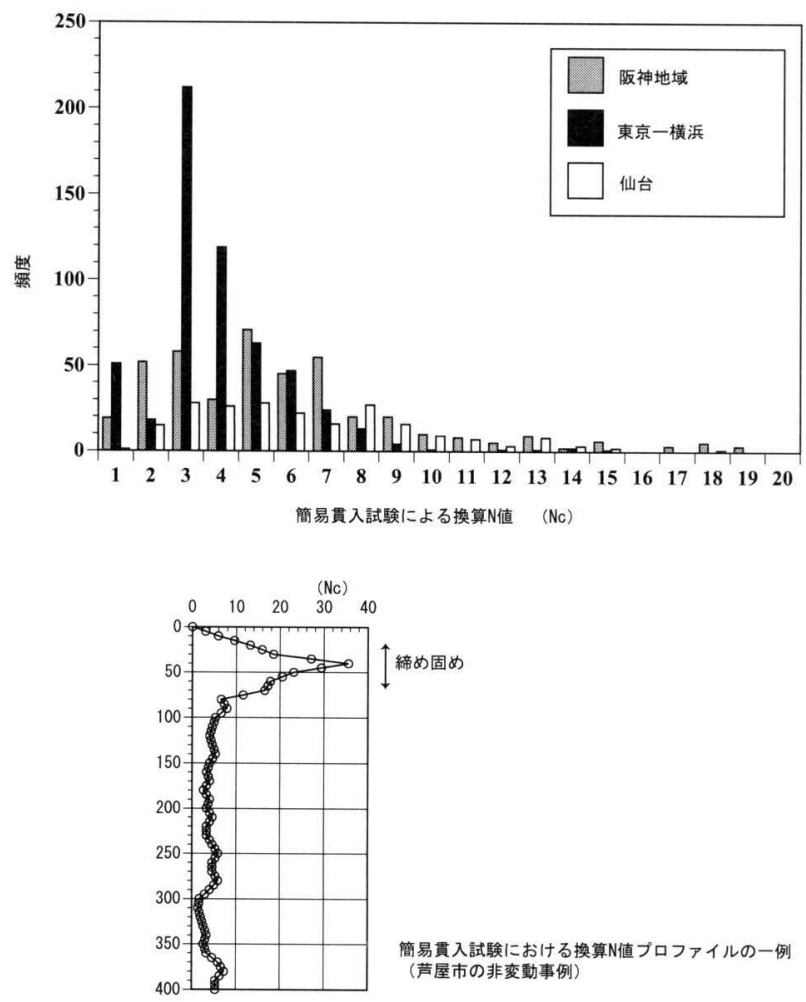

図ー4 谷埋め盛土における換算N值（Nc）の分布 Fig. 4 Distribution of the Nc-value in valley fills 

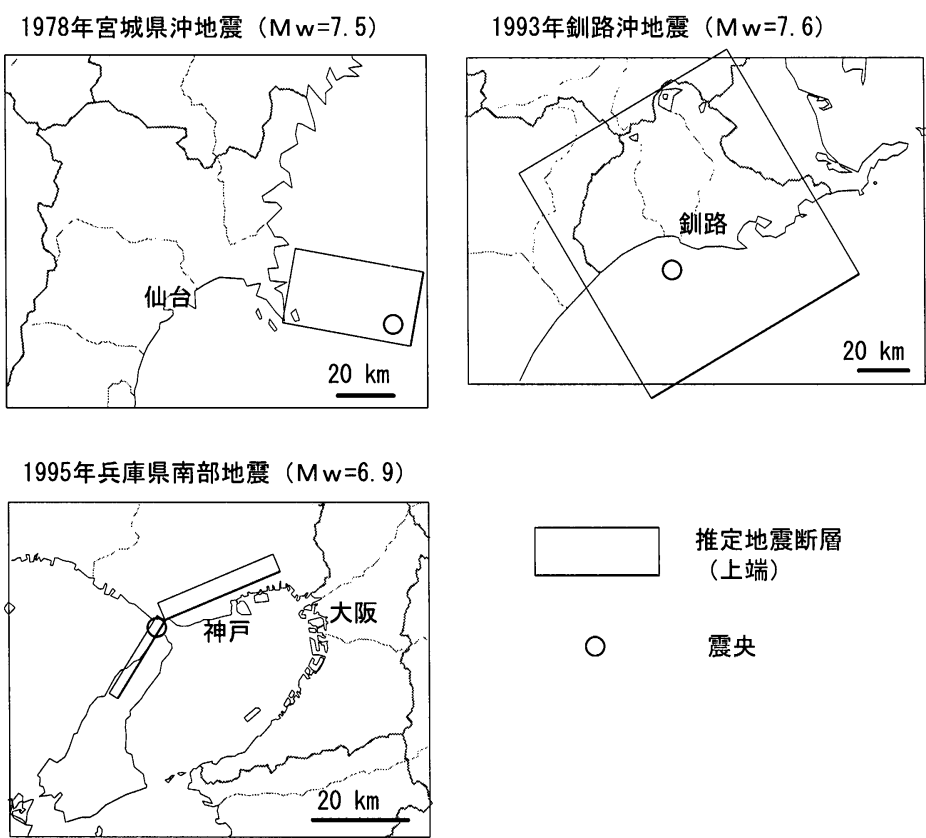

図ー 5 学習に使用した地震の震央と推定断層及びモーメントマグニチュード

Fig. 5 Earthquake parameters, epicenter, earthquake fault, and moment magnitude using in the learning process of neural network analysis

成し，現在の地形図から作成したDEMとGIS上で重ね 合わせ，差分を取って谷埋め盛土の概略の位置と形状 を把握した。その際，地図のゆがみによる誤差や数值 化の際の誤差等は手作業と現地調查によって補正した。 この作業によって，地域内の幅約 $30 \mathrm{~m}$ 以上の大規模な 谷埋め盛土を，ほほ全数について把握することが可能 である。データセットは，変動，非変動に関わらず原 則として認定できた地域内の全ての谷埋め盛土につい て作成し，変動事例数に比べて非変動事例が少ない場 合は，探索範囲を広げて変動事例と非変動事例の割合 がほほ同等となるようにデー夕の収集を行った。非変 動事例の盛土において, 盛土の縦断方向の長さに関し ては周囲の変動事例から推定した。ただし，解析にお いて縦断方向の長さに関連する要因を使用していない ので，この推定に扔ける誤差の影響は大きくないと考 えられる。

(2)首都圈南部地域の谷埋め盛土

首都圈南部の $1 / 1$ 万地形図,「自由が丘」「武蔵小杉」 「鶴見」「新横浜」の範囲（東京都目黒区〜横浜市港北 区）に分布する谷埋め盛土（総数 360 筒所）を収集し た。データセットの作成方法は, 過去の地震による変 動・非変動事例と同様である。作成したデータセット によって，この地域の大規模な谷埋め盛土は，ほほ網 羅されている。

3.3 ニューラルネットワークによる予測モデルの構成 モデルの性質を左右するパラメータとして，学習回数， 中間層ニューロンの数と学習率がある。表- 1 に使用し たパラメータのセットを示す。全ての解析で学習回数は 5000 回, 中間層ニューロンの数は 12 , 学習率は 0.15 とし
た。

学習回数は少なすぎると誤差が大きく，多すぎると過 学習となってやはり誤差が拡大する (沉化能力の低下)。 学習回数に対する誤差の変化を観察したところ，5000回 付近では平均二乗誤差（E）の変化が安定し約 $3 \%$ と最 も小さいため，今回のモデルでは5000回の学習を行うこ ととした。

中間ニューロン数が少なすぎる場合と同様に多すぎる 場合でも学習が困難になる場合があるため，最適な中間 層ニューロン数の決定はモデルの性能を左右する重要な 要因である。中間層ニューロン数が多くなると結合の総 数は飛躍的に増加するが，デー夕数（今回は事例数）に は限りがあるので中間層ニューロン数が少ない方がモデ ルとしての学習能力が高いと考えられる。しかし，中間 層ニューロン数の決定法には明確な一般的手法がないた め, 通常は多めの数から検討を始め, 徐々に中間ニュー ロン数を減らして最適な条件を見つける試行錯誤的方法 が取られている（伊藤ほか，1997）。そこで今回は，中 間層ニューロンの数を15から 9 まで変化させ，5000回学 習時における平均二乗誤差（E）が増加し始める直前の

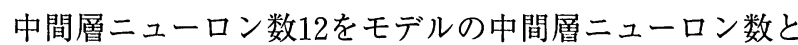
して採用した。

表一 1 ニューラルネットワークによる解析条件

Table 1 Constants using the neural network analysis

\begin{tabular}{|l|r|}
\hline 入力層ニューロンの数 & 9 \\
中間層ニューロンの数 & 12 \\
出カ層ニューロンの数 & 2 \\
学習率 & 0.15 \\
学習回数 & 5000 \\
\hline
\end{tabular}


表一 2 入力層一中間層間の結合重み（M-1 12は中間層ニューロン）

Table 2 Weight of bonds between input layer and intermediate layer $(M-1 \sim 12:$ neurons of intermediate layer)

\begin{tabular}{|c|c|c|c|c|c|c|c|c|c|c|}
\hline & 断層面からの最短距離 & $\mathrm{Mw}$ & 断層面に対する方向 & 盛土の厚さ & 盛土の幅 & 盛土の幅／厚さ比 & 盛土の底面傾斜 & 地下水の量 & 造成年代 & しきい值 \\
\hline $\mathrm{M}-1$ & -1.53 & -2.07 & 0.40 & -0.15 & -0.38 & -1.15 & -0.68 & 2.08 & -1.34 & 1.41 \\
\hline $\mathrm{M}-2$ & -2.84 & -2.21 & 11.40 & -6.36 & -13.14 & -2.93 & 1.36 & 2.81 & 0.61 & 6.85 \\
\hline$M-3$ & 8.38 & -11.81 & 10.89 & -29.19 & -4.52 & 8.35 & -15.60 & -1.78 & 6.03 & 7.59 \\
\hline$M-4$ & -20.32 & -13.44 & 6.69 & -31.00 & 30.35 & 18.55 & -7.04 & 8.09 & -8.28 & -6.25 \\
\hline$M-5$ & 3.57 & 2.32 & -23.46 & -3.56 & 8.09 & 2.82 & 2.70 & 13.02 & 2.05 & 3.79 \\
\hline$M-6$ & -3.82 & -1.23 & 4.90 & 6.01 & 7.18 & -5.68 & 3.48 & 7.47 & -8.08 & -3.90 \\
\hline$M-7$ & -14.51 & -7.72 & 17.10 & -25.52 & -8.85 & 8.84 & 6.31 & 2.79 & -0.06 & -12.09 \\
\hline$M-8$ & -0.79 & -1.23 & 2.08 & 0.78 & 1.20 & 0.51 & -0.01 & 1.34 & -0.41 & 2.14 \\
\hline $\mathrm{M}-9$ & -0.43 & -0.31 & 22.30 & 6.39 & 5.40 & 6.24 & -7.88 & -1.98 & 2.31 & -2.94 \\
\hline$M-10$ & 12.56 & 2.75 & -11.39 & -16.22 & 1.36 & 9.73 & 19.11 & 4.26 & 0.84 & 2.93 \\
\hline$M-11$ & -11.93 & 16.15 & 10.94 & 6.21 & -13.26 & -1.18 & 20.14 & 0.71 & 1.00 & -3.72 \\
\hline$M-12$ & -16.27 & -5.03 & -9.05 & 28.25 & -3.46 & -24.97 & -0.64 & 6.35 & -9.78 & 1.45 \\
\hline 結合係数の二乗和 & 1297.24 & 690.92 & 1993.43 & 3695.11 & 1530.00 & 1300.57 & 1187.93 & 378.64 & 279.46 & \\
\hline 寄与率 $(\%)$ & 10.5 & 5.6 & 16.1 & 29.9 & 12.4 & 10.5 & 9.6 & 3.1 & 2.3 & \\
\hline
\end{tabular}

ニューラルネットワークにおける結合重みの更新率を 学習率と呼び, 通常は 0.05 0.2の範囲で定義する（伊 藤，1999)。本研究では学習率を0.1，0.12，0.15，0.2 と変化させ，5000回学習時における平均二乗誤差 (E) が最小であった学習率0.15を採用した。

出力層には変動・非変動のそれぞれに対応するニュー ロンを 2 個設定した。すなわち, 変動と判定される場合 は変動ニューロンの出力が 1 に, 非変動ニューロンの出 力が 0 になるように設定した。

\section{4 ニューラルネットワークの学習結果}

過去の地震による変動・非変動事例を全て学習デー夕 とした解析（すなわちデー夕数314）について，表 -2 に入力層ニューロンと中間層ニューロン間の結合重みと 結合重みの二乗和，及びしきい值を示す。表一 3 は，中 間層ニューロンと出力層ニューロン間の結合重みとしき い值である。入力層ニューロンと中間層ニューロン間の 結合重みの二乗和は, 入力要因の影響力を平均的に表す 尺度である。表 -2 に示すように, 寄与率（各要因の結 合重み二乗和／結合重み二乗和の合計）は「盛土の厚さ」 で最も大きく，「断層面に対する方向」，「盛土の幅」，「盛 土の幅／厚さ比」，「断層面からの最短距離」,「盛土の底 面傾斜」，「モーメントマグニチュード $(\mathrm{Mw}) 」$,「地下 水の量」,「造成年代」の順に低下する。上位 5 位までの

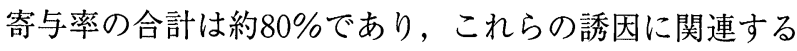
要因（断層面に対する方向, 最短距離）と盛土の規模と 形状に関連する要因（厚さ，幅，幅／厚さ比）が支配的 要因であると考えられる。

表ー4は，本研究で行ったニューラルネットワークに よる解析結果を全て示している。一部を非学習データ, 残りを学習データとしてモデルの性能をチェックした解 析 (精度評価試験) の結果も含まれる。314地点の全事 例について学習した結果, 305事例で正解が得られ, 正 解率 (適合率) は約97\%であった。釜井ほか（2002）の 多変量解析（数量化 II 類）による予測モデルでは正解率 の上限は約 $86 \%$ であり，約 $10 \%$ 上昇した。二值判別問題 としても高い正解率と言える。

地震事例別では，兵庫県南部地震で，約97\%（256事 例), 宮城県沖地震で約 $96 \%$ (54事例), 釧路沖地震で $100 \%$ （4事例）となった。不正解となった事例は, 全体で 9
表－3 中間層一出力層間の結合重み（M-1～12は中間層 ニューロン)

Table 3 Weight of bonds between intermediate layer and output layer $(\mathrm{M}-1 \sim 12:$ neurons of intermediate layer)

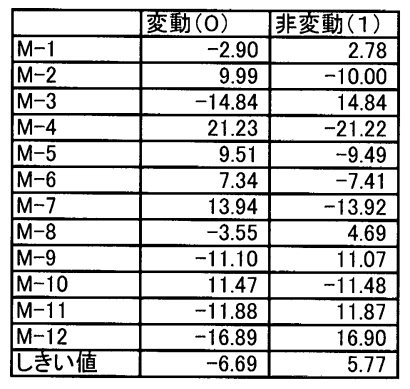

\begin{tabular}{l|l} 
桴習誤差 & $2.79 \%$ (5000回) \\
\hline
\end{tabular}

事例と少ないが，実際には変動した事例を非変動事例と 判定した場合が約 $67 \%$ と過半数を占めており，やや危険 側に外れる傾向が認められる。

\section{4. 予測モデルの評価}

\section{1 要因の感度解析}

ニューラルネット法はいわば非線形重回帰分析とも考 えられるが，BP法による結合重みの探索結果は，線形 解析の場合と異なり式の形で書き下すことが困難である。 この結果, 入力と出力の関係がブラックボックスとなっ ており，入力值の変化が出力にどのように影響を与えて いるかが直感的にわかりにくいという久点を有している。 そこで, 各要因と出力值の関係を見るため, 他の要因を 固定しながらその要因を変化させる感度解析（シミュ レーション）を行った。ただし，入力が連続值でない(8) 地下水の量と (9)造成年代は感度解析の対象とはしなかっ た。

感度解析はデータセットの出力が変動, 非変動とされ るグループ毎におこなった。対象要因以外の要因は代表 值（=平均值）に固定し，対象要因の入力值を少しずつ 変化させ, 出力值の変化を調べた。この場合の出力值は, ある要因が単独で出力に及ぼす影響の大きさを測る尺度 と考えられ, 通常の解析の結果と区別するため, 確信度 と定義する。変動, 非変動と対立する出力に対する変化 を調べているので，対象とした入力要因がモデルに対し 
表一 4 解析による正解率 (適合率)

Table 4 Ratio of correct interpretation by the neural network analysis

\begin{tabular}{|c|c|c|c|c|c|}
\hline & \multicolumn{2}{|c|}{ 学習 } & 予測（認識） \\
\hline & & & 全体 & 精度評価試験 & 精度評価試験 \\
\hline \multirow{4}{*}{$\begin{array}{c}\text { 正解率 (適合率) (\%) } \\
\text { 及び } \\
\text { (正解数 /総数) }\end{array}$} & & 全体 & $97.1(305 / 314)$ & $95.3(204 / 214)$ & $92.0(92 / 100)$ \\
\hline & \multirow{3}{*}{ 地震別 } & 兵庫県南部地震 & $97.3(249 / 256)$ & $95.1(174 / 183)$ & $94.5(69 / 73)$ \\
\hline & & 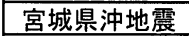 & $96.3(52 / 54)$ & $96.3(26 / 27)$ & $85.2(23 / 27)$ \\
\hline & & 釧路沖地震 & $100(4 / 4)$ & $100(4 / 4)$ & - \\
\hline
\end{tabular}

て大きな影響を与えている場合は, 入力值の変化に応じ て出力が大きく変化し, 出力 (確信度) の変化は一方が 増加すれば一方が減少するという様に相互に補完的な傾 向となる。

ただし，こうした方法で行った感度解析は多次元空間 に非線形的に存在する現象を二次元に投影して観察して いるわけであり，要因相互の関係について調べているわ けではない。したがって，現象の全体を把握しているわ けではない点に注意が必要である。図－6は要因毎の感 度解析の結果である。X軸は各要因の入力值，Y軸は, 出力值（確信度）である。以下に各要因について述べる。 それぞれに合理的な解釈が可能であり，物理的に矛盾す る要因は見られない。

(1)断層面からの最短距離

断層に近い領域では，距離は出力にほとんど影響を 与えない。しかし70kmよりも遠い領域では, 変動し やすさが増加する傾向にある。これらは, 直下型地震 としての兵庫県南部地震, プレート型地震としての宮 城県沖地震, 釧路沖地震の事例の学習効果であると考 えられる。地震としての事例数が少ないため個々の地 震の特性が強調されている可能性があるが，上記の傾
向は最大速度の距離減衰, 及び盛土の固有周期と震動 の卓越周期の影響と見ることも可能である。

すなわち, 兵庫県南部地震に様な直下型地震では震 源域の最大速度が大きく，全域でほぼ飽和しているの で変動は距離に関係なく多数発生する。一方，震源が 遠いプレート型地震場合, 最大速度の絶対值は減衰す るものの，速度スペクトルで見ると長周期側に大きな パワーを持つ震動が発生することがある。1978年宮城 県沖地震はその一例であった（宮城県，1980）。谷埋 め盛土の固有周期は通常の地盤よりも長いのが普通で あるから，こうした震動は，固有周期の長い谷埋め盛 土では不安定化する要因となると考えられる。

(2)モーメントマグニチュード

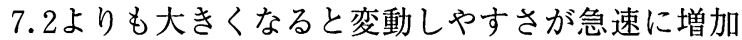
する。これは, 宮城県沖地震, 釧路沖地震の事例の学 習効果であると考えられる。規模の大きいプレート型 地震では震源が遠いにも関わらず谷埋め盛土で被害が 出ることがある。(2)モーメントマグニチュードの傾向 は(1)断層面からの最短距離とともに，こうしたプレー 卜型地震の影響を表現することが可能である。
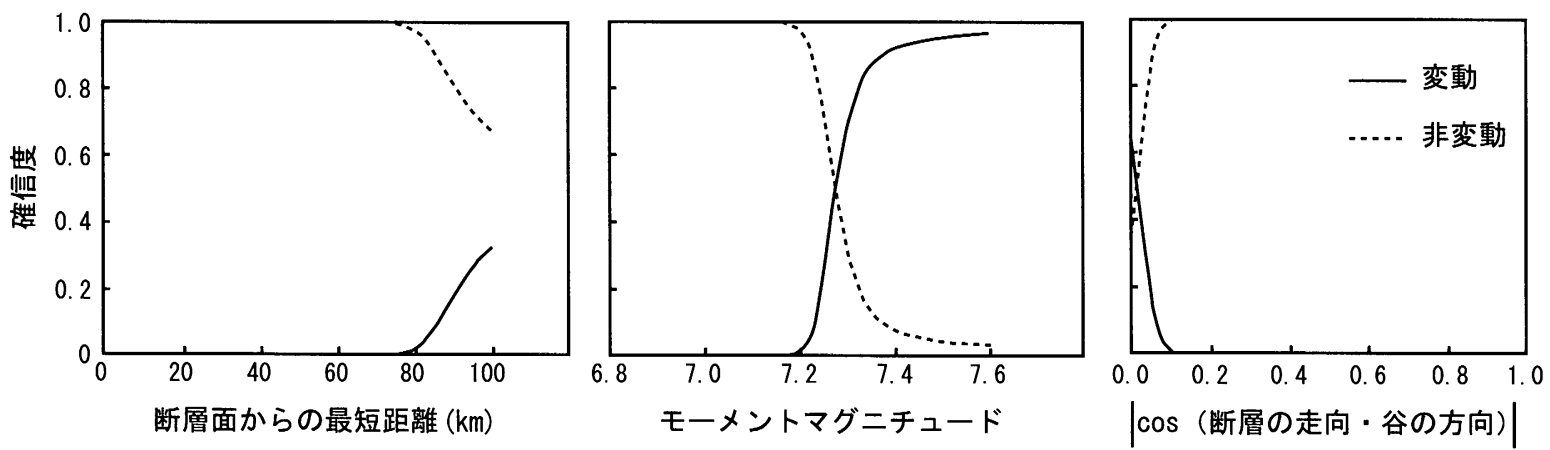

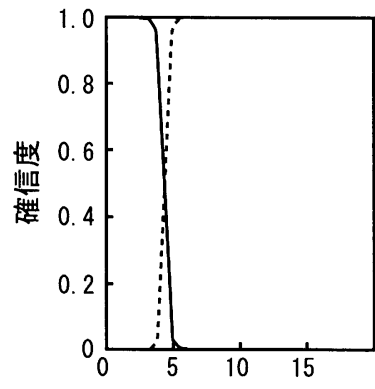

厚さ $(\mathrm{m})$

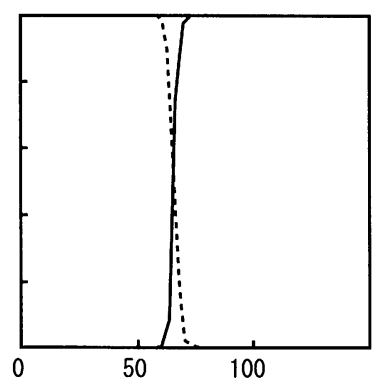

幅 (m)

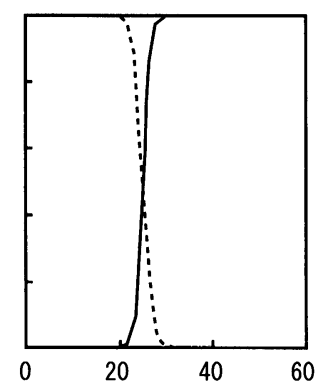

幅/厚さ

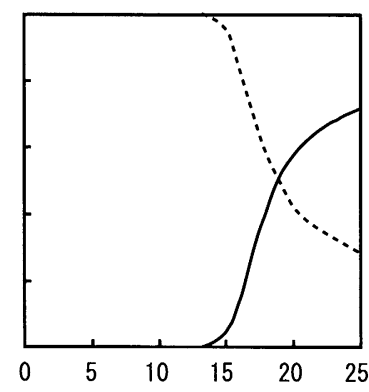

底面の平均傾斜 $\left(^{\circ}\right)$

図一 6 感度解析の結果

Fig. 6 Results of the sensitivity analysis 
(3)断層面に対する方向

断層面に対して直交方向（内積＝0）に長軸を持つ 盛土が変動しやすい。直交方向から外れるにつれて変 動しにくくなり，長軸が10度（0.18）以上斜交すると 方向の影響は見られなくなる。

断層近傍では断層の走向と直交する方向の震動が卓 越するので，谷埋め盛土の長軸が断層と直交する方向 にある場合, 強い震動が盛土全体を滑らす方向に作用 すると考えられる。

(4)盛土の厚さ

厚さが薄くなるほど変動しやすく, $5 \mathrm{~m}$ を越えると変 動しにくくなる。単位体積重量は盛土毎に大きく変化 しないと想定されるので，盛土の厚さは盛土全体の質 量と底面に対する上載荷重の影響を表していると考え られる。上記の傾向は, 盛土の質量が小さいものほど 良く動くことを示している。

(5)盛土の幅

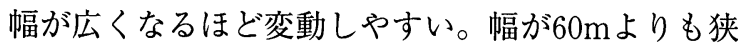
い場合は変動しにくい。幅の広い方が，側面の拘束の 影響が小さくなり変動しやすくなると考えられる。

(6)盛土の幅／厚さ比

幅／厚さの比が大きいほど変動しやすい。盛土側面 の抵抗を考えると，幅に対して薄い盛土の方が，側面 抵抗が小さいと考えられる。

(7)盛土の底面傾斜

底面傾斜が緩い領域では，傾斜は出力にほとんど影 響を与えない。しかし15度よりもよりも急な領域では, 変動しやすさが増加する。底面傾斜が急な方が底面の せん断応力が増加するので, 合理的な結果と考えられ る。底面傾斜のモデルに対する寄与率は約 $10 \%$ （全体 の 6 位）とあまり高くない。しかし，兵庫県南部地震 の事例では, 傾斜が増加するにつれて変動率は緩やか に減少し，感度分析の結果とは矛盾する傾向が得られ ている。既に述べたように，現実の事例において形状 に関する要因（厚さ，幅，底面傾斜）は，互いに独立 でない可能性が高い。したがって，こうした非線形性 の強いデータの解析は, 今回のニューラルネット解析 のように全要因を用いた非線形解析によって行う必要 がある。

\section{2 精度評価試験}

比較的事例数が多い兵庫県南部地震と宮城県沖地震の 事例から100例を認識群（予測の対象）として引き抜き， 残りを学習群として予測を行った。認識群のデー夕は学 習に反映されないので，予測（認識）の結果を精度の指 標とすることが可能である。

学習を行った 214 事例（314-100事例）についての適 合率（正解率）は, 全体で約 $95 \%$ であり, 認識群の適合 率（正解率）は全体で約 $92 \%$ であった。地震別では，兵 庫県南部地震の事例についての適合率 (正解率) は約 $95 \%$, 宮城県沖地震の事例では約 $85 \%$ であった。宮城県沖地震
の事例において適合率 (正解率) が低下した原因として は以下の 3 点が考えられる。

○そもそも学習デー夕数が少ない。

○形状要因の影響が兵庫県南部地震の事例ほど明瞭で ない

○地震としての性質や基盤地質を反映した開析谷の形 状（=谷埋め盛土の形状）が，デー夕数の多い兵庫 県南部地震の事例とは異なっている。

しかし，宮城県沖地震の事例では半数の 27 事例を学習 データに含めた予測の結果, 高い確率で残りの半数を正 しく判定することができた。このことから，地震や地形 の地域性によって正解率にやや片寄りが見られる可能性 はあるが，今回作成した予測モデルによって，谷埋め盛 土の危険度の関する簡易判定が可能であると考えられる。

\section{5. 予測モデルの具体的適用と課題}

\section{1 首都圏南部における谷埋め盛土の変動予測}

首都圈南部（1/1万地形図，「自由が丘」「武蔵小杉」 「鶴見」「新横浜」の範囲）に分布する大規模な谷埋め盛 土（360事例）について，釜井ほか（2002）は多変量解 析（数量化 II 類）を使用した変動予測を行い，予測図を 作成した。この地域に分布する谷埋め盛土は, ニューラ ルネットワークの学習に用いた兵庫県南部地震，1978年 宮城県沖地震，釧路沖地震の事例と同様，鮮新一更新統 からなる台地・丘陵地の開析谷上に造成されたものであ り, 地質, 地形条件は学習事例と類似した特徽を有して いる。このことは, 盛土の形状, 地下水に関する要因が 類似していることを示唆する。さらに，図ー4に示した ように，盛土の強度においても学習事例と大きな相違は 認められず，造成の歴史的経過も阪神地域と良く似てい る。すなわち，釜井ほか（2002）が検討対象とした首都 圏南部に分布する谷埋め盛土は, 多くの要因が今回の学 習事例と総体として類似しており，今回作成したモデル の適用範囲であると考えられる。そこで, 釜井ほか (2002) と同じ地点について，今回のニューラルネットワークに よる予測モデルを適用し, 変動・非変動の判定を行った。 学習はデータセット全体（314事例）を使用し，対象地 震を東京都（1997）の予測における神奈川県境直下の地 震（Mw7.2）とした（図-7) (損害保険料率算定会, 1998)。

図-8は, 変動・非変動の判定結果とその分布を示し ている。釜井ほか（2002）が用いた数量化 II 類は，変動 群と非変動群が分かれるように要因の重み（カテゴリー スコア）を設定し，地点ごとに要因の採点を行う手法で ある。点数の合計（サンプルスコア）の正負が，それぞ れ非変動と変動に対応するように設定されているが，こ の点は，今回のニューラルネットワーク解析において， 出力が 0 もしくは 1 で得られることと同様である。数量 化 II 類では, サンプルスコアの区間ごとに実際に変動 (も しくは非変動）した割合を計算し，確率を定義すること 
神奈川県境直下の地震（M=7.2）

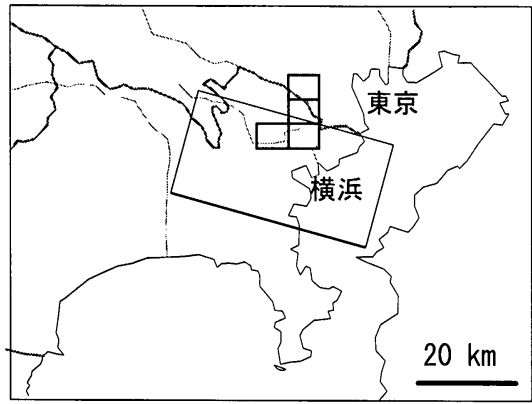

図-7 東京一横浜地域の谷埋め盛土の安定度評価において 想定した地震（東京一神奈川県境地震）

Fig. 7 Earthquake using in the stability assessment of valley-fill type landslides in Tokyo-Yokohama district

が可能である。誤差が無い場合，正負それぞれの確率は それぞれ50\%であるが，釜井ほか（2002）の解析では， 正負の分岐点における変動の確率が40\%であった。そこ で，図ー8ではそれ以上の確率となった地点を変動とし て表した。

今回の解析では, 教師值を 0 (非変動) と 1 (変動) で 与えているが，ニューラルネットワークからの出力は， アルゴリズムの関係で連続值となる。事例全体の約 $95 \%$ (300/314事例) の出力は， 0 に近い值（0.1以下）か， 1 に近い值（0.9以上）であったが，残りの約 $5 \%$ の事例

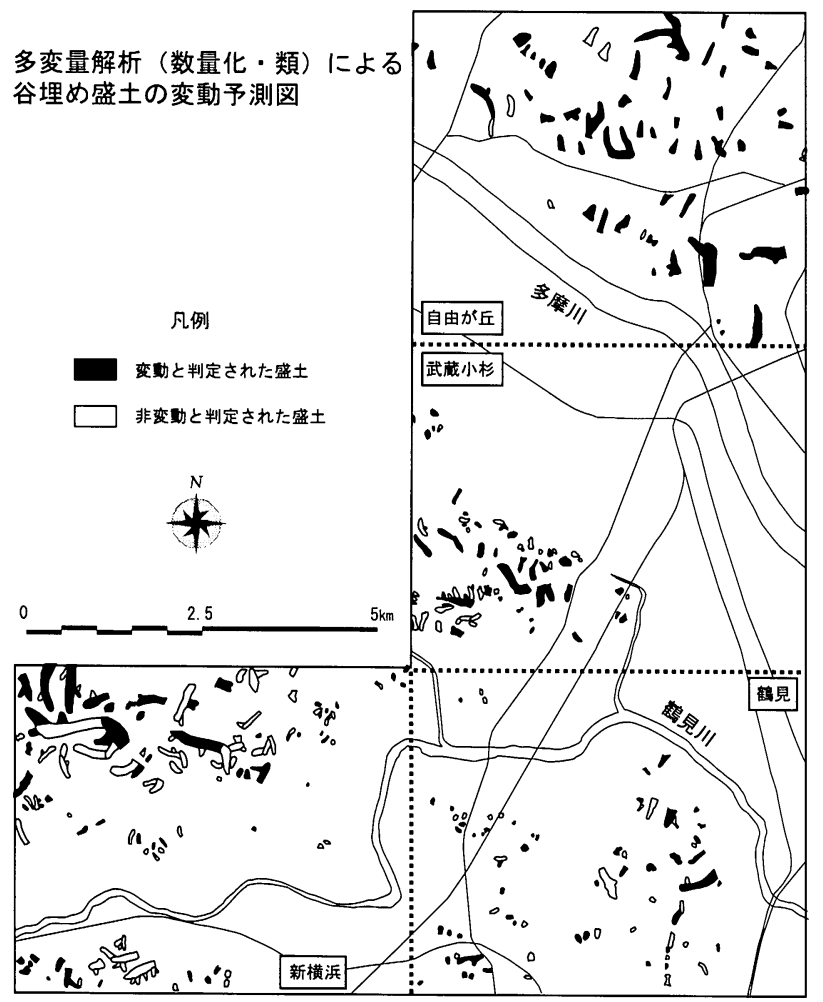

（14例）ではその範囲を超えて0.2から0.8までの出力が 得られた。この場合には, 出力層の二つのニューロン (変 動, 非変動）の出力を比較し, 高い方の数值を結論とし て採用した。この処理は，結果的に出力值の 0.5 を境界 值として変動・非変動を判断したことになる。

多変量解析（数量化 II 類）による釜井ほか（2002）の 予測と今回のニューラルネットワークによる予測は全体 的には同様の傾向であり，多摩川以北に分布する武蔵野 台地では変動と判定される地点が多く, 多摩丘陵では少 ない。首都圈南部では，一般に南西に向かうほど下位の 地層が出現し, 台地・丘陵地の起伏が増加する。これは, 谷埋め盛土の容器である谷の形状が地形面によって変化 することを意味している。すなわち，多摩川以北の武蔵 野面（武蔵野台地）では底の浅い船底型の盛土が多く， 多摩面 (多摩丘陵) では横断形状が深い箱型の谷が多く なる。既に述べたように，盛土の形状に関する要因は， 変動・非変動を分ける支配的要因の一つであり，上記の 判定結果の地域性は地形面によって盛土の形状が異なる ことを反映した結果であると考えられる（釜井ほか, 2002)。しかし，ニューラルネットワークによる予測で は釜井ほか（2002）の予測に比べ，変動と判断された地 点が18\%（40箇所）滅少した。特に南部の多摩丘陵での 減少が著しい。これは予測に誘因（地震動）に関する要 因が取り入れられた結果, 変動についてより精度高く判 定されたためであると考えられる。

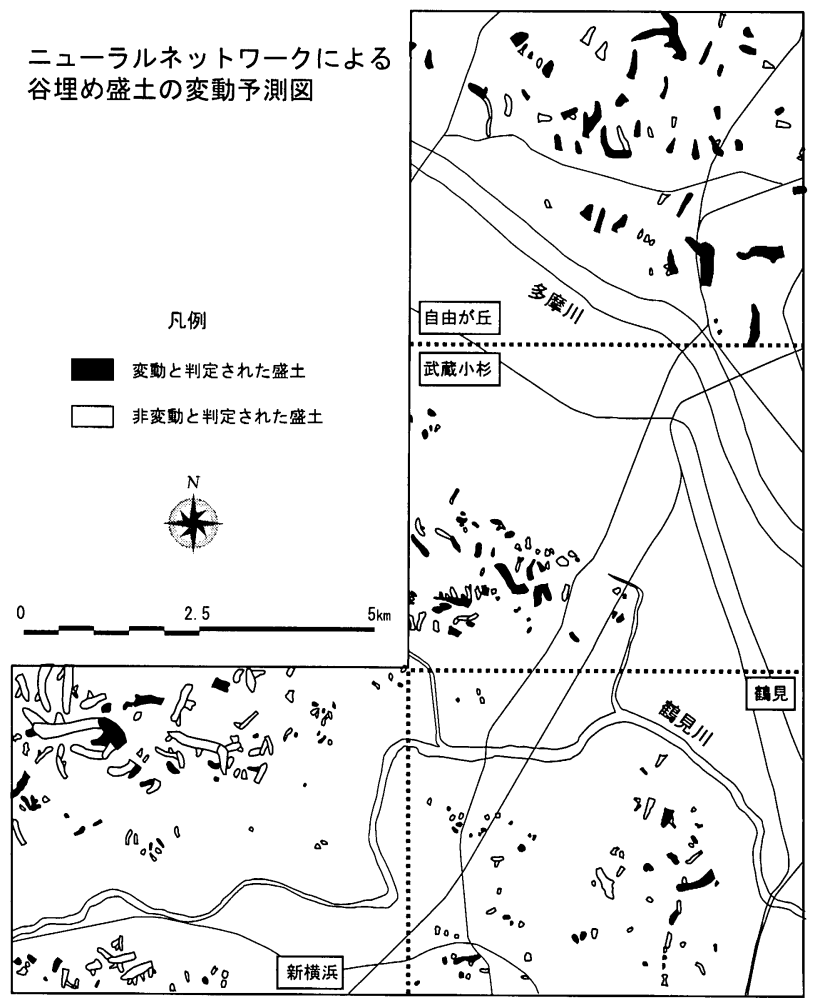

図ー8 東京〜横浜地域の谷埋め盛土に多変量解析（数量化 II 類）とニューラルネットワークによる安定度評価手法を適用した 結果

Fig. 8 Maps showing the results of the stability assessment of valley-fill type landslides in Tokyo-Yokohama district by using both the multivariate analysis and the neural network analysis 


\section{2 今後の課題}

多変量解析（数量化 II 類）による予測の問題点の多く は，非線形性の強い現象をデー夕の線形性を前提とする 手法（多変量解析）でやや強引に解析することから発生 した問題と考えられる。これに対し非線形予測法である ニューラルネットによる予測では, 上記の様な問題は発 生しにくい。正解率 (精度) の向上（約10\%の増加）, 及び感度解析結果の合理的な傾向は, このことを裏付け ていると考えられる。

しかし，今回の結果については以下の様な課題も残さ れている。

(1) 学習に用いた地震の数が依然として少ないので, データの収集を継続し, 他地区への適用に際して精度 の向上を図る必要がある。

(2) 予測の汎用性をより高めるためには, 震動特性を予 測モデルの学習要因に取り込むことが必要である。し かし, 事例解析で様々な地震のパターンに応じたデー 夕を収集するには限界がある。したがって, 室内モデ ル実験やシミュレーション，現地観測を行い，予測モ デルを補強する必要がある。

(3)これまでの検討では地盤強度は変動・非変動に対す るコントラストが弱いので, 解析要因に用いていない。 しかし，この傾向は簡易貫入試験の調査可能深度であ る $5 \mathrm{~m}$ 以浅で認められたものであり，盛土の厚さを考 えると調查深度が盛土の基底に達していない場合も多 いと考えられる。盛土基盤まで調査が行われた一部の 盛土では, 下底部に極めて軟弱な部分 (自沈) が存在 することが判明しており, 地盤強度に関しては簡便な 評価法によって，更に多くのデー夕を収集し，要因と して取り入れる努力が必要であると考えられる。

(4) 都市域の斜面には多くの防災施設等の人工構造物が 存在する。これまでの解析ではこれらの影響は無視し ているため，地点によっては判定を誤る可能性がある。 今後の修正点として考慮する必要がある。

(5) 変動する可能性が高いと判断された地点については, 安定解析を含む詳細な解析が必要である。しかし, 事 例解析から明らかなように谷埋め盛土の変動は, 縦断 面の力学バランスに基づく単純な二次元解析からは判 断できない現象である。今回の解析結果においても， 盛土長軸（盛土以前の谷の延長方向）の断層面に対す る方向が，変動の有無に影響を及ぼすことが判明した。 したがって, 今後の変動メカニズムの議論は少なくと も三次元問題として行う必要がある。

\section{6. まとめ}

今回，以下の諸点が結論として得られた。

(1) 宮城県沖地震, 釧路沖地震, 兵庫県南部地震におけ る谷埋め盛土の変動・非変動事例 314 例について, 新 たに誘因（地震）に関する要因を取り入れニューラル
ネットワークを用いた変動予測を行い, 全体の学習で 約97\%の正解率を持つモデルを構築することができた。

(2) モデルを評価するために行った感度解析では, 各要 因についてほぼ合理的に説明できる入力值と出力值の 関係が得られた。

(3) 精度評価試験では, 学習群 (宮城県沖地震, 釧路沖 地震，兵庫県南部地震：214例）で約95\%，認識（識 別）群（宮城県沖地震, 兵庫県南部地震：100例）で 約 $92 \%$ 高い正解率となり, 今回のモデルは良好な判 別モデルとして評価される。

(4) 現実にはあらゆる斜面について詳細な調查と解析を 行うことは困難であるため, 今回提案した簡易かつ合 理的な不安定化予測手法は，ハザードマップの作成や 対策の実施，及び発生した地震に対するリアルタイム 災害予測システムの構築において有用であると考えら れる。

\section{謝辞}

研究に当たって，科学研究費補助金・基盤研究 (B) (2) (課題番号15310129), 及び侏エスイーの奨学寄付金の一 部を使用した。

\section{参考文献}

浅田秋江（1982）: 宅地造成地盤の地震時危険の予測法と防止工法 に関する研究，土質工学会論文報告集，22-4，pp. 191-202. 千葉則行（1995）：1978年宮城県沖地震による地すべり・斜面崩壊 について, 兵庫県南部地震等に伴う地すべり・斜面崩壊研究 委員会報告書, 地すべり学会, pp. 203-217.

井口 隆 (1995): 谷埋盛土における地震時地すべりの事例と若干 の考察, 兵庫県南部地震等に伴う地すべり・斜面崩壊研究委 員会報告書, 地すべり学会, pp. 101-117.

伊藤則夫・白木 渡・安田 登 (1997) : 階層型ニューラルネット ワークの構造最適化に関する研究, 第 5 回システム最適化に 関するシンポジウム講演論文集, pp. $135-140$.

伊藤則夫 (1999)：自己組織化ニューラルネットワークを用いた地 盤特性值の空間分布推定手法に関する研究，金沢大学大学院 自然研究科博士論文, pp. 98-99.

KAMAI, T., KOBAYASHI, Y, JINBO, C. \& SHUZUI, H. (2000) : Earthquake risk assessments of fill-slope instability in urban residential areas in Japan, Landslides (Proc. 8th Int. Symp. Landslide), pp. 801-806, Thomas Telford.

釜井俊孝 - 守隨治雄 (2002)：斜面防災都市，理工図書，200p.

Midorikawa, S. (1993) : Preliminary analysis for attenuation of peak ground velocity on stiff site, Proc. Int. Workshop on strong motion data, vol. 2, pp. 39-48.

宮城県 (1980)：'78宮城県沖地震災害の教訓一実態と課題 - , 406p 損害保険料率算定会 (1998)：地震被害想定資料集，地震保険調查 報告28.

(社)地盤工学会 (1996)：強震記録, 阪神 - 淡路大震災調查報告書 (解 説編), pp. $108-122$.

白木 渡 - 松保重之 - 宮下英明 - 伊藤則夫 (1998)：自己組織化特 徵マップ（SOM）による斜面崩壊予測システム，構造工学論 文集, vol. 44A, pp. 453-459.

柳澤栄司・安田 進・吉田 望・若松加寿江 (1993)：住宅地の被 害, 1993年釧路沖地震・能登半島沖地震災害調査報告書, 土 質工学会, pp. $231-275$.

（原稿受付2003年 6 月 30 日，原稿受理2003年11月18日） 